\title{
TECHNOLOGY EDUCATION IN SLOVAKIA AND SCHOOL REFORM
}

\section{Danka LUKÁČOVÁ}

\begin{abstract}
A State education program, which fundamentally changes the content, methods and forms of all levels of education, was approved in year 2008. The State education program for schools according to the new school law is a hierarchically top project of education, which involves a frame model of an absolvent, frame curriculum of the educational level and its syllabus. The optional educational content is fulfilled in the school education program, which represents the second level of the participation management model. It gives the schools the possibility to specialize and fit the student needs and interests. According to the educational content we are going to focus on the quantity and quality of the technology education on the primary schools, as the praxis requests of the technical knowledge are on the rise.
\end{abstract}

Key words: technology education, State education program, school reform

\section{TECHNICKÉ VZDELÁVANIE NA SLOVENSKU A ŠKOLSKÁ REFORMA}

Resumé: V roku 2008 bol schválený Štátny vzdelávací program, ktorý zásadným spôsobom mení obsah, metódy a formy všetkých stupňov vzdelávania. Štátny vzdelávací program škôl je podl'a nového školského zákona hierarchicky najvyšši projekt vzdelávania, ktorý zahŕña rámcový model absolventa, rámcový učebný plán školského stupňa a jeho rámcové učebné osnovy. Volitelný obsah vzdelávania je napĺnaný $v$ školskom vzdelávacom programe, ktorý predstavuje druhú úroveň participatívneho modelu riadenia. Poskytuje školám možnost' profilovat' sa a vychádzat'v ústrety potrebám a záujmom žiakov. Z pohladu obsahu vzdelávania sa v tomto článku zameriame na podiel a kvalitu technického vzdelávania na základných školách, nakol'ko požiadavky praxe na technickú gramotnost' občanov stúpajú.

Kl'účové slová: technické vzdelávanie, štátny vzdelávací program, školská reforma

\section{1 Úvod}

Odporúčanie Európskeho parlamentu a Rady z 18. decembra 2006 o klúčových kompetenciách pre celoživotné vzdelávanie má snahu prispiet' $\mathrm{k}$ rozvoju kvalitného vzdelávania podporovaním a dopíňaním akcií členských štátov pri zabezpečovaní toho, aby ich systémy počiatočného vzdelávania a odbornej prípravy ponúkali všetkým mladým l'ud'om prostriedky na rozvíjanie klúčových kompetencií. Odporúča, aby „Kl'účové kompetencie pre celoživotné vzdelávanie - európsky referenčný rámec" použivali krajiny pri reforme svojich vzdelávacích sústav s ciel'om ul'ahčit' vnútroštátne reformy a výmenu informácií medzi členskými štátmi a Komisiou v rámci pracovného programu Vzdelávanie a odborná príprava 2010 s ciel'om dosiahnut' dohodnuté európske referenčné úrovne. Osvojovanie si klúčcových kompetencií žiakmi by sa malo stat' podl'a odporúčaní EÚ jedným $\mathrm{z}$ hlavných ciel'ov a rozhodujúcou zložkou kurikula všetkých typov a druhov škôl.

\section{2 Školská reforma na Slovensku}

Medzi krajiny, ktoré v dlhodobom horizonte deklarovali prípravu a potrebu reformy školstva patrí aj Slovensko. Potreba reformy vychádzala najmä z nasledovných dôvodov:

- zosúladenie školského systému podl'a dokumentov EU (dôraz na kvalitu vzdelávania a internacionalizáciu vzdelávania),

- predimenzovanost' učiva - potreba vymedzenia základného učiva,

- rýchle starnutie a prudký nárast informácií,

- potreba autonómie škôl a participácie učitel'a na tvorbe kurikula (4, s. 9),

- správa o vzdelávacej politike z r. 2003, ktorá hovorila o tom že výsledky žiakov dokazujú pokles dosiahnutého kurikula od r. 1995 do r. 2003, pričom nedošlo k zásadnejšej zmene plánovaného kurikula $(1$, s. 38)

- výsledok Slovenska v medzinárodnom testovaní PISA z r. 2006, ktorý hovorí o tom, že Slovensko je vo všetkých troch 
meraných oblastiach štatisticky významne pod priemerom krajín OECD (2).

Školská reforma bola uvedená do praxe na Slovensku r. 2008 prijatím týchto dokumentov:

- zákon o výchove a vzdelávaní. Zákon je účinný od 1. septembra 2008 a nahradil pôvodný tzv. školský zákon z roku 1984,

- štátne vzdelávacie programy (ŠVP) pre jednotlivé úrovne vzdelávania a knim aj vzorové školské vzdelávacie programy (ŠkVP) a metodika ich tvorby.

Treba mat' na zreteli, že $\mathrm{v}$ období pred reformou bola technická výchova na základných školách realizovaná len v rozsahu jednej hodiny týždenne (v ročníkoch 5 až 9), pričom na osemročných gymnáziách predmet technického zamerania absentoval úplne. Ako vyplýva $\mathrm{z}$ výskumov realizovaných $\mathrm{v}$ tomto období, obsahová náplň predmetu bola orientovaná na teoretické vedomosti žiakov. Praktické zručnosti nie sú $\mathrm{v}$ školách realizované a väčšinou ani realizovatel'né $\quad z$ dôvodu chýbajúceho priestorového a materiálneho zabezpečenia predmetu. Obsah Technickej výchovy v deviatom ročníku základnej školy je plne volitel'ný, takže zist'ovanie naplnenia vzdelávacích ciel'ov je vel'mi t’ažko uskutočnitel'né a obsah predmetu sa často zužuje na informatickú prípravu. Prenikanie informačno - komunikačných prostriedkov do základných škôl najmä vd’aka projektu Infovek ovplyvňuje spôsob vyučovania predmetu a aj jeho obsahovú náplň - vznikajú tendencie presadit' iba teoretické zameranie predmetu, ktoré však nereflektuje potreby praxe, stredných odborných škôl, ani potreby bežného používatel'a techniky. Vzniká vel'ký rozdiel medzi požiadavkami stredných odborných škôl, zamestnávatel'ov (priemyselných parkov zameraných na automobilový priemysel a elektronické prvky), a skutočným stavom technického vzdelávania na základných školách a osemročných gymnáziách.

Školská reforma schválená v roku 2008 prináša do školstva výrazné zmeny $\mathrm{v}$ základných školských dokumentoch. Štát garantuje základné vzdelanie Štátnym vzdelávacím programom, ktorý je povinný pre všetky základné školy a príslušné ročníky osemročných gymnázií. Štátny vzdelávací program (ŠVP) zahŕňa rámcový model absolventa, rámcový učebný plán školského stupňa a jeho rámcové učebné osnovy. Školy si vytvárajú vlastné školské kurikulum (školský vzdelávací program). Toto je tvorené štátnym vzdelávacím programom a volitel'nými predmetmi, ktoré tvoria cca $30 \%$ celkového rozsahu vyučovania podl'a potrieb školy, regiónu a pod. Nemusí íst' pritom vždy o nové volitel'né predmety. Túto časovú dotáciu je možné použit' aj na posilnenie už existujúcich (predpísaných) vyučovacích predmetov, ktoré sú súčast'ou štátneho vzdelávacieho programu.

Rámcový učebný plán pre základné školy s vyučovacím jazykom slovenským (stupeň ISCED 2) obsahuje tieto vzdelávacie oblasti: Jazyk a komunikácia, Príroda a spoločnost', Človek a príroda, Človek a spoločnost', Človek a hodnoty, Matematika a práca $\mathrm{s}$ informáciami, Človek a svet práce, Umenie a kultúra, Zdravie a pohyb. Technické vzdelávanie sa prednostne realizuje vo vzdelávacej oblasti Človek a svet práce prostredníctvom troch predmetov: Pracovné vyučovanie na 1 . stupni ZS , Technika a Svet práce na 2. stupni Z $\check{S}$.

\section{Technické vzdelávanie a reforma}

Ciel'om vzdelávacej oblasti Človek a svet práce je pripravit' žiakov na život v praxi a na to, aby sa v budúcnosti dokázali uplatnit' na trhu práce. Vzdelávanie $\mathrm{v}$ tejto oblasti smeruje k vytváraniu a rozvíjaniu klúčcových kompetencií žiakov tým, že vedie žiakov k:

- pozitívnemu vzt'ahu k práci a zodpovednosti za kvalitu svojich i spoločných výsledkov práce,

- osvojeniu základných pracovných zručností a návykov $\mathrm{v}$ rôznych pracovných oblastiach, $\mathrm{k}$ organizácii a plánovaniu práce a k používaniu vhodných nástrojov, náradia a pomôcok pri práci i v bežnom živote,

- vytrvalosti a sústavnosti pri plnení zadaných úloh, k uplatňovaniu tvorivosti a vlastných nápadov pri pracovnej činnosti a $\mathrm{k}$ vynakladaniu úsilia na dosiahnutie kvalitného výsledku,

- autentickému a objektívnemu poznávaniu okolitého sveta, k potrebnej sebadôvere, $\mathrm{k}$ novému postoju a hodnotám vo vzt’ahu $\mathrm{k}$ práci človeka, technike a životnému prostrediu,

- chápaniu práce a pracovnej činnosti ako príležitosti k sebarealizácii, sebavzdelávaniu a k rozvíjaniu podnikatel'ského myslenia,

- orientácii v rôznych odboroch l'udskej činnosti, formách fyzickej a duševnej práce a osvojeniu potrebných poznatkov a zručností významných pre možnost' uplatnenia, pre vol'bu vlastného profesijného zamerania a pre d’alšiu životnú a profesijnú orientáciu, 
- k rešpektovaniu environmentálnych hodnôt a chápaniu recyklácie materiálov a produktov (3).

$\mathrm{Na}$ 1. stupni základnej školy je technické vzdelávanie realizované v 20 vyučovacích hodinách vo 4. ročníku. Časová dotácia je minimálna a je predpoklad, že školy volitel'né predmety na 1 . stupni zamerajú na posilnenie takých základných predmetov ako písanie, čítanie a matematika. Pritom práca s rozličnými materiálmi a nástrojmi a vytváranie priestorovej predstavivosti je u detí mladšieho školského veku vel'mi významná.

Obsah technického vzdelávania na druhom stupni ZŠ je zameraný na vzt’ah človeka a techniky a na rozvoj vedomostí a zručností v súvislosti s používaním rôznych druhov prístrojov a nástrojov. Chýbajú témy súvisiace s rozvojom kompetencií, ktoré vedú k rozvíjaniu poznatkov a zručností potrebných pre profesijnú orientáciu žiakov ako aj podnikatel'ská výchova, ktorú je možné realizovat' v rámci technického vzdelávania. Predpokladáme, že tieto oblasti by mohli byt' náplňou volitel'ných hodín, ktoré je možné doplnit' do školských vzdelávacích programov, čím by sa rozvoj klúčových kompetencií určených pre vzdelávaciu oblast' Clovek a svet práce naplnil.

Obsah predmetu Technika v Štátnom vzdelávacom programe pre stupeň ISCED 2 je nasledovný:

7. ročník: 15 hodín ročne $(0,5$ hod/týždeň)

- Človek a technika

- Grafická komunikácia

- Materiály a technológie

8. ročník: 15 hodín ročne $(0,5$ hod/týždeň $)$

- Elektrická energia

- Technika - domácnost' - bezpečnost'

Z prezentovaných údajov vidíme, že nový predmet Technika zaradený do vzdelávacej oblasti Človek a svet práce zostal ako povinný predmet len $\mathrm{v} 7$. a 8 . ročníku s dotáciu 1 hodina týždenne. V ostatných ročníkoch zostal predmet len na úrovni volitel'ného predmetu.

Vzdelávacia oblast' Človek a svet práce má časovú dotáciu 3 hodiny za celú povinnú školskú dochádzku. Predmet Svet práce patriaci do tejto oblasti je pritom odklonený od svojho názvu a zaoberá sa vlastne pestovatel'skými prácami. $\mathrm{Na}$ realizáciu technického vzdelávania sú teda štátom garantované dve hodiny zo 192 hodín (za celú školskú dochádzku), čo percentuálne predstavuje necelé $2 \%$.

$\mathrm{Na}$ 25. medzinárodnej konferencii Technické vzdelávanie ako súčast' všeobecného vzdelávania vo Vel'kej Lomnici konanej 7. a 8. 9. 2009 sa už prejavil odraz reformných krokov voblasti technického vzdelávania $\mathrm{v}$ nespokojnosti viacerých zamestnávatel'ov (firiem) v oblasti automobilového priemyslu. Tieto názory prezentoval na konferencii zástupca Zväzu automobilového priemyslu Július Hron. Vyslovil požiadavku, aby technické vzdelávanie na základných školách bolo realizované v špeciálnom predmete od prvého stupňa základnej školy, pričom predmet bude podporený aj d'alšími aktivitami zameranými na technické vzdelávanie: technické krúžky, exkurzie vo výrobných závodoch, výstavy, aplikácie techniky a technológií vo všeobecnovzdelávacích predmetoch, využívanie pozitívnych príkladov $\mathrm{z}$ technického prostredia vo vyučovaní.

\section{Záver}

Rozvíjat' kognitívne kompetencie, učit' sa činnost'ou, sprístupňovat' žiakom metódy používané v technike, rozvíjat' schopnost' žiakov používat' a zaobchádzat' $\mathrm{s}$ technickými nástrojmi a prístrojmi - na to všetko treba mat' predovšetkým časový priestor. Ďalej je potrebná pripravenost' učitel'ov na reformné zmeny, lebo tvorba školských vzdelávacích programov je závislá len na nich.

Preto sme sa rozhodli prispiet' k reforme technického vzdelávania nasledovnými krokmi:

- pripravit' pedagogické, didaktické a metodické materiály, ktoré umožnia učitel'om zorientovat' sa v možnostiach inovácie obsahu, metód a foriem vyučovania predmetu Technika a Svet práce,

- vytvorit' webovú lokalitu, ktorá technicky vyrieši distribúciu materiálov,

- iniciovat' diskusiu učitel'ov základných a stredných škôl s odbornou skupinou garantov $\mathrm{z}$ prostredia univerzít o vhodnom základnom učive pre predmet Technika,

- prostredníctvom technicky orientovaných sút'aží zvyšovat' záujem žiakov o štúdium na technických odboroch,

- pripravit' kvalitné kurzy pre d’alšie vzdelávanie učitel'ov zamerané na tvorbu školských vzdelávacích programov ako aj učebných osnov pre volitel'né predmety Technika a Svet práce,

- pokračovat' $\mathrm{v}$ kurzoch univerzity tretieho veku orientovaných na technické odbory,

- prezentovat' techniku ako významnú súčast' života všetkých l'udí, ktorú môžeme, ak chceme pochopit' a využit' vo svoj prospech. 
Niektoré z týchto krokov už dospeli do štádia realizácie. Už niekol'ko rokov naša katedra pripravuje Technickú olympiádu - sút’až pre žiakov základných škôl. V rámci univerzity tretieho veku sme vytvorili štyri študijné programy: L’udové remeslá, Informačné technológie a edukačné aktivity seniorov, Digitálna fotografia a Hrnčiarstvo. Pre d'alšie vzdelávania učitel'ov sme vypracovali pät' kurzov. V septembri 2009 bola zaregistrovaná a uvedená do používania webová lokalita EduTech Portal ako súčast' riešenia úlohy KEGA Model komunikácie odbornej univerzitnej katedry s pedagogickou praxou $\mathrm{v}$ informačnom prostredí. Jej súčastou sú didaktické a metodické materiály pre predmet Technika určené na podporu inovácie predmetu. Aj vd'aka webovej lokalite EduTech Portal môžeme sledovat' vývoj technického vzdelávania na jednotlivých školách na Slovensku a pomáhat' učitel'om pri kreovaní nového obsahu technického vzdelávania na základných školách a osemročných gymnáziách.

\section{Literatúra}

[1] Národná správa o vzdelávacej politike. Dostupné na:

http://www.verejnapolitika.sk/ecosoc/publikacie nsvp_kapitola2., s.38

[2] PISA 2006. Národná správa. Dostupné na: http://www.statpedu.sk/buxus/docs//projekty/PIS A/pisa2006nsprava.pdf

[3] Štátny vzdelávací program pre 2. stupeň základnej školy v Slovenskej republike. ISCED 2 - nižšie sekundárne vzdelávanie. Bratislava: ŠPÚ, 2008. s. 18 - 19

[4] TUREK, I.: Zvyšovanie efektívnosti vyučovania. Bratislava: MC, 1997, ISBN 8088796-49-0. s. 9.

doc. PaedDr. Danka Lukáčová, PhD.

Katedra techniky a informačných technológií

Pedagogická fakulta UKF

Dražovská cesta 4

949 74, Nitra, SR

E-mail: dlukacova@ukf.sk 